\title{
The Impact Of Outside Director Equity Holdings On The Mix Of Outside Director Compensation
}

\author{
Guy McClain, Auburn University, USA and IESEG School of Management-- Lille, France
}

\begin{abstract}
This study investigates the impact outside director equity holdings have on the determinants of the mix of equity in outside director compensation plans. The analysis, conducted over a 4 year period from 1997-2000, is based on a sample of 89 first time adopters of equity compensation. The use of first time adopters attempts to control for the fact that many of the variables in the study are endogenously determined over time. The results indicate that the mix of equity is negatively associated with outside director holding, positively associated with the market-tobook ratio (a measure of the firm's investment opportunities) and negatively associated with return on assets (a measure of CEO bargaining power). These findings suggest that the negotiation that takes place between the CEO and outside directors regarding governance is not only affected by the firms wanting to match the marginal productivity of directors with the opportunities of the firm, but also with the equity holdings of the directors.
\end{abstract}

Keywords: outside director compensation; equity holdings; optimal contracting; CEO bargaining power

\section{INTRODUCTION}

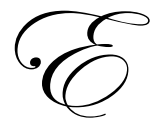

quity has become a mainstay in outside director compensation plans for its theorized ability to increase a director's willingness to monitor management by aligning the director's interests with those of shareholders (Jensen 1989; Elson 1995), thus putting the director's wealth at risk (Jensen 1993). Despite the seemingly universal use of equity in these compensation plans, the mere presence of equity compensation does not ensure better monitoring. Optimal contracting theory predicts that equity compensation is used as a mechanism to match the marginal productivity of directors with the firm's opportunities. Related, bargaining framework treats outside director compensation as a negotiation, in which the CEO and the board negotiate as to whether incentives for monitoring are in place. Thus, a CEO is able to avoid monitoring based on their perceived bargaining power. The more power the CEO has, the fewer incentives to monitor the CEO will allow to be put in place.

Regardless of the predicting theory, the empirical evidence regarding the determinants of the mix of compensation is limited. Regarding optimal contracting theory, Linn and Park (2005) find that outside director compensation is designed to attract directors whose marginal productivity interacts with the firm's investment opportunities. As the investment opportunity set increases, the need for equity compensation increases. Regarding CEO bargaining power, Ryan and Wiggins (2004) find that when a CEO's bargaining power increases over the board, compensation provides weaker incentives to monitor. Thus, high power CEOs can avoid the increased monitoring caused by equity compensation. In addition, Feng et al. (2007) test the role bargaining power and optimal contracting have in the formulation of director compensation in real estate investment trusts. They find that the mix of equity is positively related to the market-to-book ratio (a proxy for a firm's investment opportunities) and three-year stock returns (one measure of CEO bargaining power).

This paper builds on earlier research by examining an important variable that can influence the relationship between compensation mix and the determinants of that mix. Specifically, I explore the relationship between the 
outside directors' equity holdings and the mix (cash and equity) of outside director compensation. Prior research (Boyd 1996; Fich and Shivdasani 2005) indicate that equity holdings are negatively significant in the decision to adopt an equity plan, but the variable is untested in determining the mix of equity in outside director plans (Ryan and Wiggins 2004; Linn and Park 2005). Specifically, this paper attempts to answer the question: do the equity holdings of outside directors affect the level of equity compensation in outside director compensation packages?

It should be noted, however, that variables like board independence, compensation, bargaining power and other observed outcomes are endogenously determined over time. Ryan and Wiggins (2004) argue that the relationship between compensation and board characteristics represents an equilibrium outcome because the board's characteristics are predetermined when the compensation policy is set. Ryan and Wiggins (2004) test that equilibrium outcome for 1997. Linn and Park (2005), on the other hand, provide evidence as to how compensation changes as a result of changes in the firm's investment opportunity set over time. To mitigate the potential problem of endogeneity Linn and Park (2005) lag data, using year $t-3$ rather than year $t$. While that approach does help control some of the endogeneity that might exist, there is no guarantee that lagged variables are lagged far enough back. This study, therefore, focuses on firms that are initial adopters of outside director equity compensation.

By using this approach, this study makes an interesting contribution to the literature on outside director compensation by allowing for a cleaner delineation of the determinants of the mix of compensation. Outside director compensation may be both a result of the test variables (CEO bargaining power and agency costs) and a factor that influences subsequent changes in those variables. To the extent subsequent compensation anchors on initial negotiation, models that do not take the initial anchoring into account may confound interpretation of resulting coefficients. By using a sample of firms in the initial year of an outside director equity compensation plan, the study is better able to determine if the test variables are driving compensation policy or vice versa, which begins to get to the root of the debate regarding outside director compensation.

Accordingly, the study uses a sample of 89 firms in the initial year of their outside director compensation plan from the period 1997-2000. I find, as predicted, that the equity holdings of outside directors is negatively associated with the mix of equity in outside director compensation. Additionally, the mix of equity is positively related to the investment opportunities of the firm and negatively related to past accounting performance. Thus, the equity holdings of outside directors are an important factor (although previously untested), along with the firm's investment opportunities and the CEO's bargaining power when determining the mix of equity in compensation packages.

The next section discusses the literature review and develops the hypotheses. Section 3 describes the research design and the data. Section 4 provides the empirical results and the paper is concluded in Section 5.

\section{LITERATURE REVIEW AND HYPOTHESES DEVELOPMENT}

Optimal contracting theory and bargaining theory are both rooted in the perspective that board compensation exists to help mitigate agency costs between shareholders and managers and, that equity, in particular, will alleviate those barriers to effective monitoring and ultimately improve shareholder wealth (Jensen 1989; Elson 1995; Elson 1996). This theory is supported by Maug (1998) who documents that equity compensation improves an outside director's incentive to maximize shareholder wealth. Additionally, Becher et al. (2005) find that banks increased the use of equity compensation after deregulation because of the need for greater monitoring in a deregulated environment.

\subsection{Optimal Contracting Theory}

Optimal contracting theory is a response to the potential self-interested behavior of outside directors. To the extent outside directors are self-interested, they may view board service (i.e. effort) as costly and the potential for shirking (i.e. rubber stamping) exists. This self-interested behavior could be exacerbated in firms with large investment and growth opportunities because the level of effort required to gather information and monitor management is sizable given the proprietary and specialized knowledge of management (Smith and Watts 1992). Therefore, outside director compensation must engage and energize outside directors to engage in information 
gathering and monitoring and this compensation must be tied to subsequent firm performance (Jensen 1989; Elson 1995; Elson 1996).

Previous research has provided support for the optimal contracting theory of outside director compensation. Fich and Shivdasani (2005) find that the existence of an outside director equity compensation plan is significantly related to a firm's market-to-book ratio and assets for a sample of 200 Fortune 1000 firms. In addition, Linn and Park (2005) find a positive relationship between the investment opportunity set and both total compensation and percentage of equity compensation in a sample of 200 of the largest US corporations. They conclude, therefore, that outside director compensation is used to attract outside directors whose marginal productivity matches with a firm's growth opportunities and to mitigate agency costs.

\subsection{Bargaining Theory}

Another view that can exist simultaneously with optimal contracting is bargaining theory which describes the process of outside director compensation as a negotiation between the CEO and board. Hermalin and Weisbach (1998) create a model where the CEO influences the design of outside director compensation to influence the level of board monitoring. Their theory is based on the assumptions that (1) independent boards are more willing to monitor management, (2) CEOs influence the level of board independence based on their bargaining power, (3) bargaining power is determined by the board's perception of the CEO's ability, (4) perceptions of CEO ability are determined by past performance and (5) CEO's with perceived high ability influence the board to decrease board independence. Similarly, Bebchuk et al. (2002) posit that CEO's use their bargaining power to mitigate the potential positive effects contracting may have on board independence. That is, firms with CEOs that have high bargaining power use that power to develop outside director compensation schemes that have less equity. This lack of equity provides fewer incentives for the outside director to engage in costly monitoring.

Ryan and Wiggins (2004) test the bargaining power theory on a sample of $S \& P$ firms from 1997 . They find that the percentage of equity based compensation is negatively associated with the size of the board, the number of insiders on the board, CEO tenure, and past accounting performance, all indicators of a CEO with higher bargaining power.

Taken together, these theories describe a situation where the investment opportunities of the firm are one set of facts that are used in the negotiation regarding equity compensation (along with the bargaining power of the CEO). That is, the mix of equity will be related to both the investment opportunities of the firm and the bargaining power of the CEO. Therefore, my first and second hypotheses are as follows:

H1: The higher a firm's growth opportunities, the higher the percentage of equity in an outside director's compensation plan.

H2: The higher a CEO's bargaining power, the lower the percentage of equity in an outside director's compensation plan.

\subsection{Outside Director Equity Holdings}

Equity compensation is used to align the interests of outside directors with shareholders since meaningful director stock ownership will induce better monitoring of management since the directors are thinking like a shareholder. Previous research has found that outside director equity holdings are positively associated with the resistance of greenmail (Kosnik 1987), and negatively associated with the likelihood of hostile takeovers (Shivdasani 1993) and financial statement fraud (Beasley 1996).

Many outside directors, however, already own shares of stock in the firm prior to receiving equity compensation. Modern portfolio theory predicts that outside directors would be reluctant to receive additional shares of stock due to the unsystematic risk associated with concentrating wealth in a single asset. This risk may be higher for outside directors than for ordinary shareholders since outside directors have human capital value correlated with firm performance. That is, outside directors have nonfinancial reasons for joining a board, most notably the opportunity to learn, work with quality management and develop new business contacts (Lorsch and 
MacIver 1989). In addition, the outside director's continued appointment depends, in part, on the firm's success. In a study of executive stock ownership, Ofek and Yermack (2000) found that executive stock option compensation does not increase executive equity ownership. In fact, they found that when executives exercise options to acquire stock, nearly all of the stock is sold for diversification purposes. Thus, executives are reluctant to become overinvested in one asset.

Related to adoption of outside director equity compensation, the results of this variable are mixed. Vafeas (1999) found no significant relationship between outside director equity ownership and the adoption of an equity compensation plan, while Boyd (1996) and Fich and Shivdasani (2005) found a negative relationship. However, in studies regarding the determinants of the mix of compensation for outside directors this variable is not tested. Neither Ryan and Wiggins (2004) nor Linn and Park (2005) test the impact of outside director equity holdings on the percentage of equity included in compensation. Therefore, my third hypothesis is as follows:

H3: The higher the outside directors' equity ownership, the lower the percentage of equity in outside director compensation plans.

\section{RESEARCH DESIGN}

\subsection{Empirical Specification}

Mix of equity (MOE) is the dollar amount of equity compensation divided by the dollar value of total compensation. All compensation data was collected from firm proxy statements (form DEF 14A) filed with the SEC's Edgar Database. Total compensation is calculated as the total dollar value of cash and equity compensation. Cash compensation is the total cash paid for board retainers and meeting fees. Equity compensation is the total of all stock grants and stock options awarded as valued by the Black-Scholes (1973) method. Similar to Certo et al. (2008), I assume options are awarded at the money (exercise price is equal to market price on the day of the option grant which is assumed to be the price at the end of the most recent fiscal year) and time maturity is ten years.

CEO bargaining power is proxied for by return on assets (ROA). Similar to Ryan and Wiggins (2004), I use a lagged variable. Where they use a three-year average, I use the 5-year average return on assets computed by dividing income from continuing operations before interest expenses and taxes by average total assets. I use an accounting measure of performance to capture bargaining power, rather than a stock measure, because accounting measures are a better measure of CEO performance than stock measures. The reasoning being that accounting earnings are more sensitive to firm-specific changes in value and reflect factors under the executive's control (Lambert and Larker 1987; Sloan 1993). In contrast, variations in stock returns can be explained by both CEO actions and market-wide fluctuations outside the CEO's control (Fama 1976; Fama 1990).

The firm's investment and growth opportunities are measured by the market-to-book ratio (MTB). This measure has been used in recent research on outside director compensation (Feng et al. 2007; Cordeiro et al. 2007; Ryan and Wiggins 2004). A similar measure was used by Linn and Park (2005). MTB is calculated as the market value of equity plus the book value of total liabilities divided by total assets. ODEH is the percentage of outside director equity holdings relative to total outstanding common stock, consistent with Vafeas (1999), Boyd (1996) and Fich and Shivdasani (2005).

Following previous studies (e.g., Ryan and Wiggins 2004; Linn and Park 2005; Fich and Shivdasani 2005), I control for agency costs (SIZE, DTE) CEO similarity (CEOCOMP) and governance characteristics (OUTBOD, TENURE, and DUAL). SIZE, measured as the log of total assets and has a predicted, positive coefficient because as a firm grows in size, agency costs increase; therefore, the need for more monitoring increases (Jensen and Meckling 1976). DTE is the debt-to-equity ratio and no prediction is made regarding the sign of its coefficient. On the one hand, a negative relationship may be expected because as a firm's leverage increases, that firm is less likely to use equity compensation because of the conflict between debtholders and stockholders (Bryan and Klein 2004). On the other hand, a positive relationship may be expected because as a firm's leverage increases, cash requirement also increases and less cash is available for compensation, thus equity compensation becomes attractive (Bryan et al 2000). 
CEOCOMP is included to control for the similarity of CEO and outside director compensation since both compensation packages are approved by the same compensation committee (Crystal 1991) and is predicted to have a positive coefficient. It is measured as the natural $\log$ of total CEO compensation - salary, bonus and equity grants (item TDC1 of CompuStat). OUTBOD is the percentage of outsiders on the board and no prediction is made as to the expected sign on its coefficient. To the extent that outside directors are more diligent and want more incentives to monitor, a positive relationship may be expected (Vafeas 1999). But, to the extent governance mechanisms can be substitutes (Rediker and Seth 1995), a negative relationship may be expected. TENURE is the natural log of the years a CEO has been in that position at the firm. Similar to Hermalin and Weisbach (1998), a CEO's tenure reflects the CEO's ability to influence the board. It is used as a governance control variable since more recent performance is a better indicator of power in a bargaining game (Hermalin and Weisbach 1998). DUAL is an indicator variable equal to 1 if the CEO is also chairman of the board and zero otherwise. This variable is used in numerous studies (for example, Ryan and Wiggins 2004; Feng et al. 2007) as a measure of a CEO's power. Since there is little variability, however, in this variable (75\% rate in this study, 69\% rate in Ryan and Wiggins 2004) it used a governance variable to control for the influence the CEO has on board direction and activities.

To test the stated hypotheses regarding the influence of outside director equity holdings, CEO bargaining power and optimal contracting as determinants of outside director compensation, I use a basic OLS regression model in which mix of equity is the dependent variable and proxies for outside director equity holdings. CEO bargaining power, optimal contracting, and outside director equity holdings are the major independent variables. The empirical model is specified as follows:

MOE $_{\text {it }}=\beta_{0}+\beta_{1}$ SIZE $_{i t}+\beta_{2}$ DTE $_{\text {it }}+\beta_{3}$ CEOCOMP $_{\text {it }}+\beta_{4}$ OUTBOD $_{\text {it }}+\beta_{5}$ TENURE $_{i t}+\beta_{6}$ DUAL $_{i t}+\beta_{7}$ MTB $_{\text {it }}$ $+\beta_{8} \mathrm{ROA}_{\mathrm{it}}+\beta_{9} \mathrm{ODEH}_{\mathrm{it}}+$ error $_{\mathrm{it}}$

Where $\mathrm{i}$ indicates the firm and $\mathrm{t}$ indicates the year;

$\mathrm{MOE}_{\mathrm{it}}=$ the mix of equity, computed as the dollar value of equity divided by the dollar value of total compensation

SIZE $_{\text {it }}=$ the log of total assets

DTE $_{\text {it }}^{=}=$debt-to-equity ratio, calculated as total liabilities divided by total equity

$\mathrm{CEOCOMP}_{\mathrm{it}}=$ the log of the total compensation of the CEO

OUTBOD $_{\text {it }}=$ percentage of outsides on the board, calculated as the number of outside directors on the board divided by total board members, as reported in a firm's proxy statement

TENURE $_{\text {it }}=$ the log of the number of years a CEO has been in place

DUAL $_{\text {it }}=1$ if the CEO is also chairman of the board, 0 otherwise

$\mathrm{MTB}_{\text {it }}=$ market-to-book ratio, computed as the market value of equity plus book value of total liabilities divided by total assets

$\mathrm{ROA}_{\text {it }}=5$ year, average return on assets computed by income from continuing operations before interest expenses and taxes divided by average total assets

$\mathrm{ODEH}_{\mathrm{it}}=$ percentage of common shares owned by outside directors, computed as the number of shares of common stock owned by outside directors divided by number of outstanding shares of common stock, as reported in the firm's proxy statement 


\title{
3.2 Sample and Data
}

The sample of firms used to investigate the determinants of outside director compensation mix was selected in multiple stages. First, firms in their initial year with an outside director equity compensation policy were identified by querying Standard \& Poor's ExecuComp database for all outside directors who received zero stock grants or stock options in 1997, 1998, 1999, and 2000 and 734 firms were found. Because this study investigates the role of governance on firm performance, 415 firms were excluded that operate in an industry in which government regulation acts as an additional layer of monitoring. An industry is considered to have government regulation if it is a financial services firm or a utility. Next, individual queries on each of the remaining 319 firms were performed to identify the first year in which outside directors received either stock grants or stock options. One hundred eightyseven firms were eliminated in which equity compensation has been used in previous years.

Of the 132 remaining firms, 16 firms were eliminated because financial information was not available and 27 were eliminated because they did not have 5 years of additional financial information beyond the plan adoption date due to either mergers/ acquisitions (23) or delisting of trading securities (4). Thus, there is a final sample of 89 firms.

Once a firm was identified as feasible and plan adoption date found, financial variables were obtained from Compustat while market related data were obtained from CRSP. Board of director variables such as compensation and composition are collected from firm proxy statements filed on the Securities and Exchange Commission's EDGAR database. Table 1 presents the distribution of the sample firms by industry and year.

Table 1

Distribution of sample firms by year of equity plan adoption and Standard Industry Code (SIC) Panel A: The distribution by year of equity plan adoption

\begin{tabular}{|c|c|}
\hline Year of equity plan adoption & Number of firms in sample \\
\hline 1997 & 9 \\
\hline 1998 & 25 \\
\hline 1999 & 26 \\
\hline 2000 & 29 \\
\hline & Total \\
\hline
\end{tabular}

Panel B: The distribution by SIC

SIC
1
2
3
4
5
7

\author{
Industry Description \\ Primary \\ Manufacturing- nondurables \\ Manufacturing- durables \\ Transportation \\ Wholesalers and Retailers \\ Business Services \\ Total
}

Firms in sample
6
16
27
6
12
$\underline{22}$
89

\section{RESULTS}

\subsection{Descriptive Statistics}

Summary statistics on outside board of director compensation are presented in Table 2. On average, outside boards of directors receive average (median) total compensation of $\$ 121,414(\$ 62,544)$, with a range of $\$ 2,217,520$ to $\$ 13,392$. Total compensation is comprised of average (median) cash compensation of $\$ 26,768$ $(\$ 27,000)$. This cash compensation is comprised of an average (median) cash retainer of $\$ 19,548(\$ 20,000)$ and an average (median) per meeting fee of $\$ 1,079(\$ 1,000)$. The average number of meetings was 6.69 for an average (median) cash from meetings of $\$ 7,220(\$ 6,000)$. The lowest cash compensation was zero, while the highest was $\$ 70,000$. The average (median) value of equity compensation awarded to outside directors was $\$ 94,646(\$ 28,544)$ with a high of $\$ 2,217,520$ and a low of $\$ 3,392$. 
Table 2

Descriptive statistics of director compensation in the year of the plan adoption ( $n=89)$

\begin{tabular}{|c|c|c|c|c|c|}
\hline & Mean & Median & Maximum & Minimum & Standard Deviation \\
\hline \multicolumn{6}{|l|}{ Cash Compensation } \\
\hline Annual cash retainer & $\$ 19,548$ & $\$ 20,000$ & $\$ 55,000$ & $\$ 0$ & $\$ 13,578$ \\
\hline Fee per meeting & $\$ 1,079$ & $\$ 1,000$ & $\$ 5,000$ & $\$ 0$ & $\$ 948$ \\
\hline Number of meetings & 6.69 & 6 & 18 & 2 & 2.87 \\
\hline Cash from meetings & $\$ 7,220$ & $\$ 6,000$ & $\$ 20,000$ & $\$ 0$ & $\$ 5,327$ \\
\hline Total cash compensation & $\$ 26,768$ & $\$ 27,000$ & $\$ 70,000$ & $\$ 0$ & $\$ 14,946$ \\
\hline \multicolumn{6}{|l|}{ Equity Compensation } \\
\hline Value of stock grants & $\$ 94,646$ & $\$ 28,544$ & $\$ 2,217,520$ & $\$ 3,392$ & $\$ 249,665$ \\
\hline Total compensation & $\$ 121,414$ & $\$ 62,544$ & $\$ 2,217,520$ & $\$ 13,392$ & $\$ 247,154$ \\
\hline
\end{tabular}

Table 3 presents descriptive statistics for the all variables. The mean (median) 5-year stock returns are $12.8 \%(3.9 \%)$, with a maximum of $1004.6 \%$ and a minimum of $-19.8 \%$. The mean (median) 5 -year return on assets is $29.9 \%(27.2 \%$ ), with a maximum of $616.2 \%$ and a minimum of $-106.9 \%$. The average tenure of a CEO was 9.3 years, with the longest tenure being 38 years. Seventy-five percent of CEOs also serve as chairman of the board. Market-to-book has a mean (median) of $2.36 \%$ (1.67\%). All variables (except for DUAL) exhibit considerable variance across the sample.

\subsection{Univariate Analyses}

Correlations among the mix of equity compensation, agency costs, CEO similarity, and governance characteristics are presented in Table 4. First, the mix of equity is positively correlated with the market-to-book ratio and firm size. Size is also positively related to CEO compensation and the market-to-book ratio. Duality is negatively related to debt-to-equity and positively related to the percentage of outsiders on the board and CEO tenure. In addition, return on assets is also negatively related with the percentage of outsiders on the board. To further test these relationships, multivariate analyses are performed.

Table 3

Summary statistics of test variables and control variables at the time of equity plan adoption (n=89)

\begin{tabular}{lccccc}
\hline Variables & Mean & Median & Maximum & Minimum & Standard Deviation \\
SIZE & 20.900 & 20.838 & 24.154 & 17.744 & 1.394 \\
DTE & 2.03 & 1.18 & 29.6 & 0.15 & 3.81 \\
CEOCOMP & 15.159 & 14.265 & 17.741 & 11.672 & 15.864 \\
OUTBOD & $62.5 \%$ & $63.0 \%$ & $91.6 \%$ & $21.1 \%$ & $15.6 \%$ \\
TENURE & 9.3 & 5 & 38 & 1 & 9.2 \\
DUAL & $75.0 \%$ & & & & \\
MTB & 2.36 & 1.67 & 10.8 & 0.74 & 1.93 \\
ROA & $29.9 \%$ & $27.2 \%$ & $616.2 \%$ & $-106.9 \%$ & $61.1 \%$ \\
ODEH & $2.3 \%$ & $0.25 \%$ & $73.0 \%$ & $0.0 \%$ & $9.6 \%$ \\
\hline
\end{tabular}

Variable definitions:

SIZE is the log of total assets;

DTE is the debt-to-equity ratio, calculated as total liabilities divided by total equity;

CEOCOMP is the log of the total compensation of the CEO;

OUTBOD is the percentage of outsides on the board, calculated as the number of outside directors on the board divided by total board members, as reported in a firm's proxy statement;

TENURE is the log of the number of years a CEO has been in place;

DUAL is 1 if the CEO is also chairman of the board, 0 otherwise;

MTB is the market-to-book ratio, computed as the market value of equity plus book value of total liabilities divided by total assets;

ROA is the 5 year, average return on assets computed by income from continuing operations before interest expenses and taxes divided by average total assets;

ODEH is the percentage of common shares owned by outside directors, computed as the number of shares of common stock owned by outside directors divided by number of outstanding shares of common stock, as reported in the firm's proxy statement. 


\subsection{Multivariate Analyses}

Table 5 presents the results of the OLS regression results of my empirical model. I follow a stepwise approach in introducing the variables. Model 1 estimates the determinants of the mix of compensation by examining variables proxying for agency costs (size and debt to equity), CEO similarity (CEO compensation) and governance characteristics (percentage of outsiders on the board, CEO tenure, and duality). Model 2 introduces variables related to bargaining power (return on assets) and optimal contracting theory (market-to-book ratio). Model 3 introduces a measure of the outside director's equity holdings. Model 4 examines the same basic relationships as Model 3 but adds a variable that interacts the market-to-book ratio with the outside directors' equity holdings. These variables are interacted as they provide natural tension against each other. Importantly, each of the variables in Table 5 is significant at the $p<0.01$, suggesting that the group of variables of equity mix that have been identified in this study is important in determining the mix of equity.

Table 4

Pearson correlations between the variables used in the OLS regressions

\begin{tabular}{|c|c|c|c|c|c|c|c|c|c|c|c|}
\hline & Variable & 1 & 2 & 3 & 4 & 5 & 6 & 7 & 8 & 9 & 10 \\
\hline 1 & MOE & 1 & & & & & & & & & \\
\hline 2 & SIZE & $.452 * * *$ & 1 & & & & & & & & \\
\hline 3 & DTE & -.032 & .013 & 1 & & & & & & & \\
\hline 4 & CEOCOMP & -.134 & $.548 * * *$ & .036 & 1 & & & & & & \\
\hline 5 & OUTBOD & -.172 & .152 & -.101 & .069 & 1 & & & & & \\
\hline 6 & TENURE & .131 & .031 & -.048 & .094 & -.015 & 1 & & & & \\
\hline 7 & DUAL & .092 & .007 & $-.219 * *$ & -.086 & $.328 * * *$ & $.215^{* *}$ & 1 & & & \\
\hline 8 & MTB & $.447 * * *$ & $.302 * * *$ & -.150 & -.019 & -.149 & -.088 & .087 & 1 & & \\
\hline 9 & ROA & -.076 & .038 & -.132 & .088 & $-.189 *$ & -.031 & .088 & .069 & 1 & \\
\hline 10 & ODEH & -.157 & .134 & -.036 & -.056 & .102 & .042 & -.049 & -.139 & -.061 & 1 \\
\hline$*$ & Significant at & 0.10 level & & & & & & & & & \\
\hline$* *$ & Significant at & 0.05 level & & & & & & & & & \\
\hline$* * *$ & Significant at & 0.01 level & & & & & & & & & \\
\hline
\end{tabular}

Focusing on Model 1 and the agency cost, CEO similarity and governance characteristic variables, the only significant determinant of equity mix is firm size. As expected, larger firms require more monitoring and are therefore more likely to use a higher mix equity when compensating directors. Next, focusing on the optimal contracting and bargaining power variables in Model 2, support is given for H1, but not H2, as the market-to-book ratio is significant and return on assets is not. Thus, as a firm's investment opportunities increase, the percentage of equity in outside directors compensation also increases (similar to Linn and Park 2005 and Feng et al. 2007). Size continues to be significant. Adding the percentage of outside director equity holdings in Model 3 unveils both return on assets and the percentage of outside director equity holdings as significant in determining the mix of equity. Return on assets has a negative relationship with mix of equity providing support for $\mathrm{H} 2$, indicating that CEOs that achieve good performance require less monitoring through a lower mix of equity. H3 is supported by the negative relationship between outside director equity holdings and mix of equity. Firms where outside directors own a higher percentage of equity include a lower percentage of equity in their outside director compensation plans. Finally, in Model 4, where the interaction between market-to-book and outside director equity holdings is included in the model: support for $\mathrm{H} 1, \mathrm{H} 2$ and $\mathrm{H} 3$ is maintained but the interacted variable is not significant. 
Table 5

Results of OLS regression on determinants of outside director compensation $(n=89)$

\begin{tabular}{|c|c|c|c|c|}
\hline \multirow[b]{2}{*}{ Variables } & \multicolumn{4}{|c|}{$\begin{array}{c}\text { Coefficient } \\
(t \text {-statistics })\end{array}$} \\
\hline & (1) & (2) & (3) & (4) \\
\hline Intercept & $\begin{array}{c}.7514604 * * * \\
(2.11)\end{array}$ & $\begin{array}{c}.6669363 * * \\
(1.99)\end{array}$ & $\begin{array}{c}.6964581 * * \\
(2.11)\end{array}$ & $\begin{array}{c}.6328303 * \\
(1.91)\end{array}$ \\
\hline SIZE & $\begin{array}{c}.1036651 * * * \\
(4.51)\end{array}$ & $\begin{array}{c}.0798407 * * * \\
(3.43)\end{array}$ & $\begin{array}{c}.0881354 * * * \\
(3.77)\end{array}$ & $\begin{array}{c}.0851667 * * * \\
(3.64)\end{array}$ \\
\hline DTE & $\begin{array}{c}-.0022287 \\
(-0.27)\end{array}$ & $\begin{array}{c}.0002229 \\
(0.03)\end{array}$ & $\begin{array}{c}-.0009467 \\
(-0.12)\end{array}$ & $\begin{array}{c}-.000545 \\
(-0.07)\end{array}$ \\
\hline CEOCOMP & $\begin{array}{c}.0410261 \\
(1.45)\end{array}$ & $\begin{array}{c}.0278975 \\
(1.01)\end{array}$ & $\begin{array}{c}.0305909 \\
(1.12)\end{array}$ & $\begin{array}{c}.0340844 \\
(1.25)\end{array}$ \\
\hline OUTBOD & $\begin{array}{c}-.2645768 \\
(-1.49)\end{array}$ & $\begin{array}{c}-.2368323 \\
(-1.35)\end{array}$ & $\begin{array}{c}-.2024763 \\
(-1.17)\end{array}$ & $\begin{array}{c}-.2311263 \\
(-1.33)\end{array}$ \\
\hline TENURE & $\begin{array}{c}.0174923 \\
(0.507)\end{array}$ & $\begin{array}{c}.0279581 \\
(1.11)\end{array}$ & $\begin{array}{c}.0290934 \\
(1.17)\end{array}$ & $\begin{array}{c}.0369418 \\
(1.46)\end{array}$ \\
\hline DUAL & $\begin{array}{c}.0961695 \\
(0.192)\end{array}$ & $\begin{array}{c}.0775774 \\
(1.10)\end{array}$ & $\begin{array}{c}.0680377 \\
(0.98)\end{array}$ & $\begin{array}{c}.0659929 \\
(0.95)\end{array}$ \\
\hline МТВ & & $\begin{array}{c}.0419972 * * * \\
(3.21)\end{array}$ & $\begin{array}{c}.0376977 * * * \\
(2.88)\end{array}$ & $\begin{array}{c}.0339389 * * * \\
(2.54)\end{array}$ \\
\hline ROA & & $\begin{array}{c}-.0639639 \\
(-1.65)\end{array}$ & $\begin{array}{c}-.0669691 * \\
(-1.75)\end{array}$ & $\begin{array}{c}-.0678275 * \\
(-1.78)\end{array}$ \\
\hline ODEH & & & $\begin{array}{c}-4.234881^{*} \\
(-1.83)\end{array}$ & $\begin{array}{c}-1.253089 * \\
(-1.88)\end{array}$ \\
\hline MTB X ODEH & & & & $\begin{array}{c}.8032303 \\
(1.33)\end{array}$ \\
\hline $\mathrm{F}$ & $4.82 * * *$ & $5.84 * * *$ & $5.72 * * *$ & $5.37 * * *$ \\
\hline Model $\mathrm{R}^{2}$ & .2068 & .3055 & .3254 & .3318 \\
\hline $\begin{array}{ll}* & \text { Significant at the } 0.10 \text { level } \\
* * & \text { Significant at the } 0.05 \text { level } \\
* * * & \text { Significant at the } 0.01 \text { level }\end{array}$ & & & & \\
\hline
\end{tabular}

\section{CONCLUSION}

The board of directors is the mechanism by which management is monitored and ultimately disciplined (Fama 1980; Jensen 1983). Considerable attention, therefore, has been given to the means by which boards can become more effective monitors of management. Included in these recommendations is the suggestion equity aligns the interests of shareholders and directors. Previous research has theorized that the inclusion of equity in outside director compensation is a response to optimal contracting and CEO bargaining power, but has neglected to test the role of the equity holdings of outside directors. This paper directly tests the role the equity holdings of outside directors has on the mix of equity in outside director compensation.

My analysis, conducted over a 4 year period from 1997 to 2000, was applied to a sample of 89 firms that are first time users of equity in their outside director compensation plans. Using a sample of first time adopters helps to control for the endogeneity of compensation and performance variables. The dependent variable in the empirical model is the mix of equity calculated as the dollar value of equity compensation divided by the dollar value of all compensation. The findings, as predicted, indicate that the mix of equity is negatively associated with the outside directors' equity holdings. The findings also indicate that the mix of equity is positively correlated with measures of optimal contracting and negatively associated with measures of CEO bargaining power. These findings suggest that the negotiation that takes place between the CEO and outside directors regarding governance is not only affected by the firms wanting to match the marginal productivity of directors with the opportunities of the firm, but also with the equity holdings of the directors.

This paper is subject to limitations due to sample size. Therefore, any generalization of these results to other firms should proceed with caution. Also, the sample is from a time period prior to Sarbanes-Oxley. Since the 
passage of Sarbanes-Oxley the demands, compensation, qualifications, and time commitments required by outside directors have change dramatically. While these results do shed light on the fundamental differences among compensation components, director attitudes and responsibilities may have changed in such a way as to override these findings.

\section{AUTHOR INFORMATION}

Guy McClain is an assistant professor of accounting at Auburn University and an Affiliated Professor at the IESEG School of Management in Lille, France. His main research interests are corporate governance, compensation and financial reporting/disclosure.

\section{REFERENCES}

1. Beasley, M., An empirical analysis of the relation between the board of director composition and financial statement fraud. Accounting Review. Vol. 71, No. 4, pp. 443- 465, 1996.

2. Bebchuk, L., Fried J. \& Walker D., Managerial power and rent extraction in the design of executive compensation. The University of Chicago Law Review, Vol. 69, pp. 751-846, 2002.

3. Becher, D., Campbell T. \& Frye M., Incentive compensation for bank directors: the impact of deregulation. Journal of Business, Vol. 78, No. 5, pp. 1753-1777, 2005.

4. Black, F. \& Scholes M., The pricing of options and corporate liabilities. Journal of Political Economy, Vol. 81, No. 3, pp. 637-654, 1973.

5. Boyd, B., Determinants of us outside director compensation. Corporate Governance, Vol. 4, No. 4, pp. 202-211, 1996.

6. Bryan, S. \& Klein A., Non-management director options, board characteristics, and future firm investments and performance. Unpublished working paper, New York University, 2004.

7. Bryan, S., Hwang L. \& Klein, A., Compensation of outside directors: an empirical analysis of economic determinants. Unpublished working paper, Baruch College, 2000.

8. Certo, S., Dalton C., Dalton D. \& Lester R., Boards of directors' self interest: expanding pay in corporate acquisitions? Journal of Business Ethics, Vol. 77, No. 2, pp. 219-230, 2008.

9. Cordeiro, J., Veliyath R., \& Romal J., Moderators of the relationship between director stock-based compensation and firm performance, Corporate Governance: An International Review, Vol. 15, No. 6, pp.1384-1393, 2007.

10. Crystal, G., Why ceo compensation is so high. California Management Review, Vol. 34, No. 1, pp. 9-29, 1991.

11. Elson, C., The duty of care, compensation, and stock ownership. University of Cincinnati Law Review. Vol. 63, No. 2, pp. 649-711, 1995.

12. Elson, C., Director compensation and the management-captured board - the history of a symptom and a cure. Southern Methodist University Law Review, Vol. 50, No. 1, pp. 127-174, 1996.

13. Fama, E., Foundations of Finance, Basic Books, New York, NY, 1976.

14. Fama, E., Agency problems and the theory of the firm. Journal of Political Economy, Vol. 88, No. 2, pp. 288-307, 1980.

15. Fama, E., Stock returns, expected returns, and real activity. Journal of Finance, Vol. 45, No. 4, pp. 1089$1108,1990$.

16. Feng, Z., Ghosh C., \& Sirmans, C., Director compensation and CEO bargaining power in REITs. Journal of Real Estate Finance andEconomics, Vol. 35, No. 3, pp. 225-251, 2007.

17. Fich, E. \& Shivdasani A., The impact of stock-option compensation for outside directors on firm value. Journal of Business, Vol. 78, No. 6, pp. 2229- 2254, 2005.

18. Hermalin, B. \& Weisbach M., Endogenously chosen boards of directors and their monitoring of the ceo. The American Economic Review, Vol. 88, No. 1, pp. 96- 118, 1998.

19. Jensen, M., Organization theory and methodology. The Accounting Review, Vol. 2, No. 2, pp. 319- 339, 1983.

20. Jensen, M., Eclipse of the public corporation. Harvard Business Review, Vol. 67, No. 5, pp. 61-74, 1989.

21. Jensen M., The modern industrial revolution, exit, and the failure of internal control systems. Journal of Finance, Vol. 48, No. 3, pp. 831-880, 1993. 
22. Jensen, M. \& Meckling W., Theory of the Firm: Managerial Behavior, Agency Costs and Ownership Structure. Journal of Financial Economics, Vol. 3, No. 4, pp. 305-360, 1976.

23. Kosnik, R., Greenmail: a study of board performance in corporate governance. Administrative Science Quarterly. Vol. 32, No. 2, pp. 163-185, 1987.

24. Lambert, R. \& Larcker D., An analysis of the use of accounting and market measures of performance in Executive Compensation Contracts. Journal of Accounting Research, Vol. 25, pp. 85-125, 1987.

25. Linn, S. \& Park D., Outside director compensation and the investment opportunity set. Journal of Corporate Finance, Vol. 11, No. 4, pp. 680-715, 2005.

26. Lorsch, J. \& MacIver E., The Reality of America's Corporate Boards, Harvard Business School Press, Cambridge, MA, 1989.

27. Maug, E., Large shareholders as monitors: is there a trade-off between liquidity and control? The Journal of Finance, Vol. 53, No. 1, pp. 65- 98, 1998.

28. Ofek, E., \& Yermack, D., Taking stock: equity-based compensation and the evolution of managerial ownership, The Journal of Finance, Vol. 55, No. 3. Pp. 1367-1384, 2000.

29. Rediker, K. \& Seth A., Boards of directors and substitution effects of alternative governance mechanisms. Strategic Management Journal, Vol. 16, No. 2, pp. 85-99, 1995.

30. Ryan, H. \& Wiggins R., Who is in whose pocket? director compensation, board independence, and barriers to effective monitoring. Journal of Financial Economics, Vol. 73, No. 3, pp. 497- 524, 2004.

31. Sloan, R., Accounting earnings and top executive compensation. Journal of Accounting and Economics, Vol. 16, No. 1-3, pp. 55-100, 1993.

32. Shivdasani, A., Board composition, ownership structure, and hostile takeover. Journal of Accounting and Economics. Vol. 16, No. 1-3, pp. 167-198, 1993.

33. Smith, C. \& Watts R., The investment opportunity set and corporate financing, dividend and compensation policies. Journal of Financial Economics, Vol. 32, No. 3, pp. 263-92, 1992.

34. Vafeas, N., Determinants of the adoption of director incentive plans. Journal of Accounting, Auditing, and Finance, Vol. 14, No. 4, pp. 453- 474, 1999. 


\section{NOTES}

